\title{
Selection of Innovative Entrepreneurship Education Path of Contemporary College Students
}

\author{
Hongmei Sheng, Delong Bu
}

\section{Shandong Jianzhu University, Ji'nan, 250101, China}

\begin{abstract}
The planning of college students' innovative entrepreneurship education path can effectively improve the actual effects of college students' innovative entrepreneurship education. The factors that should be considered in selecting the innovative entrepreneurship education path of college students are analyzed and the feasible paths and guarantee for path implementation are put forward in this paper, hoping to provide references to the relevant research.
\end{abstract}

Key words: College students; innovative entrepreneurship; education path

The innovative entrepreneurship education, aiming at guiding and encouraging the entrepreneurship of college students, is a major model for talents cultivation of college at present and also the important measure to update the education content and reform the teaching path. If the scientific research, social service and talents cultivation can be closely combined to change from emphasis on knowledge teaching to emphasis on quality and ability cultivation, it will greatly drives the employment and entrepreneurship. However, to achieve this goal, the innovative entrepreneurship education should be implemented and the path selection is a necessary way for the implementation of innovative entrepreneurship education. Recently, the author has been always engaged in the educational works related to this and finds an operational innovative entrepreneurship path in the process of continuous exploration and practice, which has obtained good effects.

I. Factors considered in selecting the innovative entrepreneurship education path

(I) Directive spirit of Ministry of Education

Ministry of Education once clearly pointed out in the relevant opinions that 
innovative entrepreneurship education was a new teaching model and philosophy. The author thinks innovative entrepreneurship education is special, which is mainly embodied in the following aspects: first, the education is based on the certain entrepreneurship demand of students and students' major background cannot be taken as the sole factor to consider, that is, the students must have certain entrepreneurship direction; second, the innovative entrepreneurship course should be embodied in the basic features of "experience course” and "practice course” and the course setting should have certain nature of "training course"; third, the practical teaching should run through the textbook and the textbook should be designed with practical teaching as the main line; fourth, the teacher should be clear about its responsibilities, serve students' innovative entrepreneurship, point the way for students and at the same time, take students' entrepreneurship practice and experience as the core in the innovative entrepreneurship teaching, conduct self-education positively, continuously accumulate entrepreneurship experience in the practice to significantly improve its entrepreneurship skills.

(II) Current situation of college students' innovative entrepreneurship demand

It is found after survey that less than $30 \%$ college students actively accept the entrepreneurship training and less than 20\% students have strong entrepreneurship intention and less than 5\% students have entrepreneurship potential and interest. It is found by conducting a survey of graduates that less than $1 \%$ students are successful in starting their own business. It is clear from these figures that the innovative entrepreneurship education should be conducted specifically for different college students.

(III) College’s acceptance of innovative entrepreneurship education

Affected by the traditional education model, the core is professional education, around which the course setting, discipline construction and teaching staff construction are conducted. Considering the character of students, the directional education of a certain career direction is conducted. For the development of college students-centered innovative entrepreneurship education model, the college will take a certain period of time to adapt to it. At the same time, the college also thinks that the 
college students' entrepreneurship is a matter of future and they should study hard at school. This is reasonably to a certain degree, but also partial for college students with successful entrepreneurship. For innovative entrepreneurship education at college, it is better to choose the path easily accepted by the college and students as the breakthrough point.

(IV) Degree of permission under innovative entrepreneurship education conditions

Innovative entrepreneurship education at college needs the support of certain material and spiritual conditions, for example, innovative entrepreneurship management system, school leader's attention. The educator should work and find the reasonable and scientific path actively in the actual work to promote college students' innovative entrepreneurship education.

\section{Selection of innovative entrepreneurship education path of college students}

The selection of innovative entrepreneurship education path of college students is mainly consisted of 4 nodes and is guaranteed by corresponding guarantee mechanism. The two constitute the main path of college students' innovative entrepreneurship education. The nodes in innovative entrepreneurship education are discussed below.

(I) General education

General education, based on college student's career planning course, with all the students as the object, set up in the second or third semester of undergraduate years, with 20 class hours, is mainly to teach students cultivation of innovative entrepreneurship consciousness, creation of entrepreneurship environment, cultivation of entrepreneurship quality and other relevant contents. The general education mainly aims at guiding college students to build certain innovative entrepreneurship consciousness, conducting effective evaluation of their entrepreneurship ability and effectively enhance their entrepreneurship interest so as to provide good conditions for the subsequent specialized education.

(II) Specialized education

Specialized education is mainly for those students with entrepreneurship potential, interest and certain entrepreneurship conditions, with 48 class hours. 
Students for specialized education are selected by interview and entrepreneurship ability assessment and learn contents of five plates, such as innovative ability expand by practice course. During teaching, students should jointly establish the entrepreneurship group or team, select the entrepreneurship project and closely combine the entrepreneurship process and experience. The specialized education aims at guiding students to master the entrepreneurship knowledge, have certain entrepreneurship ability and accumulate certain entrepreneurship experience in the educational process so as to better lay a solid foundation for the future entrepreneurship.

(III) Project incubation

Project incubation, which is mainly conducted in the incubator, mainly refers to the whole process of the entrepreneurship project of student or student team from germination to new starting of enterprise. The project incubation needs many preparations, such as construction of incubation site, provision of relevant facilities, setup of “college students' innovative entrepreneurship fund” and formulation of fund management measures. By the above works, the incubation functions of incubator are fully played to guide the students to enter the specific implementation stage of entrepreneurship project, which is transplanted into the society after maturity.

(IV) Social transplantation

When the college students' entrepreneurship project enters the society, the tutor and project management team should building the project tracking supporting system, help the students' innovative project in a certain period of time, and guide the growth of students' innovative enterprise.

All in all, the general education plays a fundamental role in the above four nodes. Under the guidance of innovative entrepreneurship consciousness, partial students are outstanding in the education, with certain entrepreneurship potential, and enter subsequent intensive education and entrepreneurship experience stage; the specialized education plays a core role, in which the students are arranged to have entrepreneurship practice and experience to obtain certain entrepreneurship experience and produce entrepreneurship project under the guidance of tutor and then 
make it operable and concrete to create conditions for entering the incubator stage; project incubation plays a critical role and the education of this link is an important embodiment of innovative entrepreneurship education achievements and also an important measure of improving the success rate of college students' entrepreneurship; the social transplantation is the nodal point and the work of this link directly shows the smooth growth of entrepreneurship project and proves the realization of goal that drives the employment with entrepreneurship.

\section{Guarantee for implementation of innovative entrepreneurship education path}

(I) Build the innovative entrepreneurship education course system

When the college students' innovative entrepreneurship education system is built, the course system combining required course, lecture, specialized course and practice course should be built combined with the teaching objective, in which the required course is Introduction to College Students' Entrepreneurship, with 1 credit and 18 class hours. It is set up in the third semester of undergraduate years and brought into the teaching programme of cultural quality education and professional education, fully realizing the organic integration of required course and professional course system and promoting the effective connection of practice activity of innovative entrepreneurship education and practical teaching of specialized course of college students.Specialized course mainly refers to the practical education for students with entrepreneurship interest and potential as well as certain entrepreneurship condition. The course is a teaching form of specialized class, with 3 credits and 48 class hours. There are 30 students in the specialized class, lasting for 2 months. For the lecture, the expert database should be built first, in which the school employs some successful entrepreneurs in the society to hold entrepreneurship lecture at school. Practice course, conducted in the third to seventh semester of undergraduate years combined with the teaching requirement, is to concretize the contents of practical teaching and extend it into the practical project of each stage so as to develop the specific operation scheme of practical project.

(II) Do the basic work of innovative entrepreneurship education well 
First, compile textbook. The textbook for college students' innovative entrepreneurship education should be designed according to innovative entrepreneurship consciousness and entrepreneurship preparation, which should be closely combined with the teaching goal. The compilation of textbook should refer to the foreign successful experiences in innovative entrepreneurship and pay attention to the combination of theory and practice to continuously cultivate students' operational ability. Second, build the teaching team. During innovative entrepreneurship education, a teaching team based on full-time teachers should be built and the following works should be done well: 1) set two full-time teachers in the teaching and research section of innovative entrepreneurship and employ 4 part-time teachers in a contracting form to constitute the core teaching team; 2) build a part-time teacher team, employ professional teacher and enterprise in the society as part-time entrepreneurship teachers and maintain stable working relationship with them; 3) have strict requirements on teacher's admission, for example, the teacher engaged in innovative entrepreneurship education should not only have strong teaching ability, but also have certain entrepreneurship experience and working experience; 4) further strengthen the teachers' training strength, guide the teacher to actively participate in various training activities, arrange the teacher to conduct survey in the enterprise, guide the teacher to participate in academic exchange and encourage the teacher to participate in innovative entrepreneurship practice; 5) positively conduct teaching research activity and effectively improve the teacher's teaching quality by collective less preparation and textbook compilation and other means; 6) conduct information construction to provide conditions for teaching.

(III) Set up college students' entrepreneurship incubator

The task of incubator is to provide services for college students' entrepreneurship, which are embodied into the development of entrepreneurship guidance and training, acceptance of college students' internship. The incubator should be constructed by stage and step, accommodate 10 entrepreneurship incubation projects and be provided with the relevant facilities, such as water, electricity, house and network. In addition, the software support should be perfected and the supporting system corresponding to 
the entrepreneurship guidance should be built. At the same time, the innovative entrepreneurship education should be managed, the project management team should be built and the sound innovative entrepreneurship management system should be established.

(IV) Set up college students’ innovative entrepreneurship fund

1 Purpose: provide fund for college students' innovative entrepreneurship activity;

2 Source of fund: social subsidy is the main force, coordinated by school investment;

3 Range of fund use: support students' innovation, invention and creation as well as students' project incubation and conduct project development with local government;

4 Fund management: specify the fund use limit and be disbursed in the fund by training expense or loan and other forms.

\section{Conclusion:}

In conclusion, the talents cultivation of college should pay more attention to the cultivation of innovative entrepreneurship talents and the improvement of students' comprehensive ability. At the same time, the cultivation of innovative entrepreneurship ability should be concerned by the change of cultivation model and the problems and difficulties in cultivation should be studied and solved to promote the concept change of college, government and students and make them form a joint force so as to further promote the implementation of the college students' innovative entrepreneurship education cultivation model. Innovative entrepreneurship education, aiming at guiding the entrepreneurship of college students, is the major model for talents cultivation of college. If the scientific research, social service and talents cultivation can be closely combined to change from emphasis on knowledge teaching to emphasis on quality and ability cultivation, it will greatly drives the employment and entrepreneurship. The path selection is a necessary way to implement the innovative entrepreneurship education. The selection of innovative entrepreneurship education path of college students is discussed in this paper for your reference.

\section{References:}

[1] Li Haoran. Discussion on Model of University Science Park Promoting Innovative 
Entrepreneurship Education-—Taking Education Model of Yanshan University Science Park Prompting the Cultivation of College Students' Innovative Entrepreneurship Practice Ability[J]. China Business \& Trade, 2013, (29).

[2] Li Qiubin. Basic Model and Path Selection of Innovative Entrepreneurship Education of College Students[J]. Journal of Minjiang University, 2014, (1).

[3] Li Qunru. Exploration and Practice on College Students' Innovative Entrepreneurship Education Path[J]. Human Resource Management, 2011, (6).

[4] Liu Hongmin. Institutional Foundation, Path Selection and Policy Proposal of University Science Party Promoting College Students’ Innovative Entrepreneurship[J]. Science and Technology Management Research, 2012, (24).

[5] Shi Xianfeng. Discussion on Conducts of College Communist Youth League in College Students' Innovative Entrepreneurship Education[J]. China Electric Power Education, 2009, (15).

[6] Hang Mengjie. Thought and Practice on Strengthening College Students' Innovative Entrepreneurship Education[J]. Journal of University of Electronic Science and Technology of China (Social Sciences Edition), 2009, (5).

[7] Bei Jinghong. Innovative Entrepreneurship Education: Path Selection Breaking Through Bottleneck of College Students' Employment Difficulty[J]. Journal of Zhejiang Youth College, 2009, (4).

[8] Cao Jianhui, Zhou Hebing, Luo Yifan. College Students' Innovative Entrepreneurship Education Model[J]. Research and Exploration in Laboratory, 2010, (8).

[9] Li Guohu. Status Analysis and Countermeasure Study of Innovative Entrepreneurship Education of College Students[J]. Contemporary Vocational Education, 2013, (11). 